AEC RESEARCH AND DEVELOPMENT REPORT<smiles>CC(C)(C)C1(C)CCCCC1</smiles>

\section{THE MOLYBDENUM HEXAFLUORIDE-HYDROGEN FLUORIDE TRIPLE POINT CURVE AND ITS APPLICATION TO A METHOD OF ANALYSIS}

\author{
AUTHOR: \\ W. D. Hedge
}




\section{DISCLAIMER}

This report was prepared as an account of work sponsored by an agency of the United States Government. Neither the United States Government nor any agency Thereof, nor any of their employees, makes any warranty, express or implied, or assumes any legal liability or responsibility for the accuracy, completeness, or usefulness of any information, apparatus, product, or process disclosed, or represents that its use would not infringe privately owned rights. Reference herein to any specific commercial product, process, or service by trade name, trademark, manufacturer, or otherwise does not necessarily constitute or imply its endorsement, recommendation, or favoring by the United States Government or any agency thereof. The views and opinions of authors expressed herein do not necessarily state or reflect those of the United States Government or any agency thereof. 


\section{DISCLAIMER}

Portions of this document may be illegible in electronic image products. Images are produced from the best available original document. 
Printed in the United States of America. Available from Clearinghouse for Federal Scientific and Technical Information, National Bureou of Standards,

U.S. Department of Commerce, Springfield, Virginia 22151

Price: Printed Copy $\$ 3.00$; Microfiche $\$ 0.65$

\section{LEGAL NOTICE}

This report was prepared as an account of Government sponsored work. Neither the United States, nor the Commission, nor any person acting on behalf of the Commission:

A. Makes any warranty or representation, expressed or implied, with respect to the accuracy, completeness, or usefulness of the information contained in this report, or that the use of any information, apparatus, method, or process disclosed in this report may not infringe privately owned rights; or

B. Assumes any liabilities with respect to the use of, or for damages resulting from the use of any information, apparatus, method, or process disclosed in this report.

As used in the above, "person acting on behalf of the Commission" includes any employee or contractor of the Commission, or employee of such contractor, to the extent that such employee or contractor of the Commission, or employee of such contractor prepares, disseminates, or provides access to, any information pursuant to his employment or contract with the Commission, or his employment with such contractor. 
Date of Issue: March 22, 1968

Report Number: $\quad \mathrm{K}-1698$

Subject Category: CHEMISTRY

THE MOLYBDENUM HEXAFLUORIDE-HYDROGEN FLUORIDE TRIPLE POINT CURVE AND ITS APPLICATION TO A METHOD OF ANALYSIS

W. D. Hedge

Technical Division

\section{LEGAL NOTICE} This report was prepared as an account of Govern ahe half of the Commission: This report was prepted nor any person acting on bed implied, with respect to the accustates, nor the Com warranty or representation, expressed onted in this report, or that the use A. Makes any warranty orrepre of the information contalned in thls report may not infringe racy, completeness, or uaratus, method, or process disclosed in information, appar privately owned rights; or

B. Assumes any lisbilities with reshod, or piocoss disclosed in this report. use of any Information, apparatus, method, or behalf of the Commission" ind the extent that

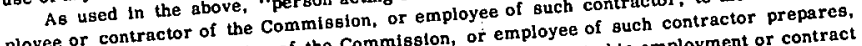
ployee employee or contractor of the Comm information pursuant to his employenent or con such eminates, or provides access to, any inth such contractor.

with

.

UNION CARBIDE CORPORATION

NUCLEAR DIVISION

Oak Ridge Gaseous Diffusion Plant

Oak Ridge, Tennessee 
THIS PAGE

WAS INTENTIONALLY

LEFT BLANK 
Report Number: K-1698

Subject Category: CHEMISTRY

Title: THE MOLYBDENUM HEXAFLUORIDEHYDROGEN FLUORIDE TRIPLE POINT CURVE AND ITS APPLICATION TO A METHOD OF ANALYSIS

Author: W. D. Hedge

\section{ABSTRACT}

The triple point curve for the binary system molybdenum hexaf'luoridehydrogen fluoride has been determined over the range of 0.0 to 5.0 mole percent hydrogen fluoride. This system is represented by the following general equation:

$$
\Delta t=A\left(N_{2}\right)+B\left(N_{2}\right)^{2}+C\left(N_{2}\right)^{3}
$$

where $\Delta t$ is the depression of the triple point of pure molybdenum hexafluoride in degrees centigrade, $\mathbb{N}_{2}$ is the mole fraction of hydrogen fluoride, and $A, B$, and $C$ are constants with

$$
\begin{aligned}
& A=159.86-129.19(R)+36.44(R)^{2} \\
& B=-3624.5+2965.0(R)-407.5(R)^{2} \\
& C=26239.0-17875.0(R)-1796.2(R)^{2}
\end{aligned}
$$

$R$ is the ratio of liquid volume to total volume.

The deviations resulting from non-ideality are discussed. Corrections for these deviations are applied by extrapolation of observed triple point depressions and ratios of liquid volume to total volume as represented by the above general equation. A method is also presented to estimate the liquid, gross, and vapor compositions. 


\section{THIS PAGE \\ WAS INTENTIONALLY \\ LEFT BLANK}


THE MOLYBDENUM HEXAFLUORIDE-HYDROGEN FLUORIDE TRIPLE POINT CURVE
AND ITS APPLICATION TO A METHOD OF ANALYSIS

A nondestructive analytical method was needed to measure the purity of molybdenum hexafluoride. Since hydrogen fluoride was the major impurity encountered in this laboratory, cryoscopic analyses appeared to be the most promising. Preliminary calculations from the heat of fusion of molybdenum hexafluoride (I) indicate that the molal freezing (triple) point constant is $38.3^{\circ} \mathrm{C}$ per mole of hydrogen fluoride per 1000 grams of molybdenum hexafluoride, assuming an ideal solution. The purpose of this study is to provide a nondestructive method of analysis for molybdenum hexafluoride.

\section{SUMMARY}

The triple point curve for the binary system molybdenum hexafluoridehydrogen fluoride has been determined over the range of 0.0 to 5.0 mole percent hydrogen fluoride. This system is represented by the following equation:

$$
\Delta t=67.11\left(\mathrm{~N}_{2}\right)-1067.0\left(\mathrm{~N}_{2}\right)^{2}+6567.8\left(\mathrm{~N}_{2}\right)^{3}
$$

(Equation 1)

where $\Delta t$ is the triple point depression of pure molybdenum hexafluoride in degrees centigrade, and $\mathrm{N}_{2}$ is the mole fraction of hydrogen fluoride.

A method is presented for correcting the deviations resulting from nonideality of the binary system. Extensions of the observed triple point depressions of different ratios of liquid volume to total volume are represented by the following equation:

$$
\Delta t=A\left(N_{2}\right)+B\left(N_{2}\right)^{2}+C\left(N_{2}\right)^{3}
$$

where

$$
\begin{aligned}
& A=159.86-129.19(R)+36.44(R)^{2} \\
& B=-3624.5+2965.0(R)-407.5(R)^{2} \\
& C=26239.0-17875.0(R)-1796.2(R)^{2}, \text { and }
\end{aligned}
$$

$\Delta t$ is the triple point depression of molybdenum hexafluoride

and

$$
\mathrm{N}_{\boldsymbol{\varepsilon}} \text { is the mole fraction of hydrogen fluoride }
$$

$R$ is the ratio of liquid volume to total volume.

\section{EQUIPMENT}

\section{APPARATUS}

A $50 \mathrm{ml}$ triple point cell (figure 1) was used to contain the solution. It was a 4-1/2-inch Monel cylinder, 1-5/16-inch-diameter, with a small 
DWG. NO. G-67-149

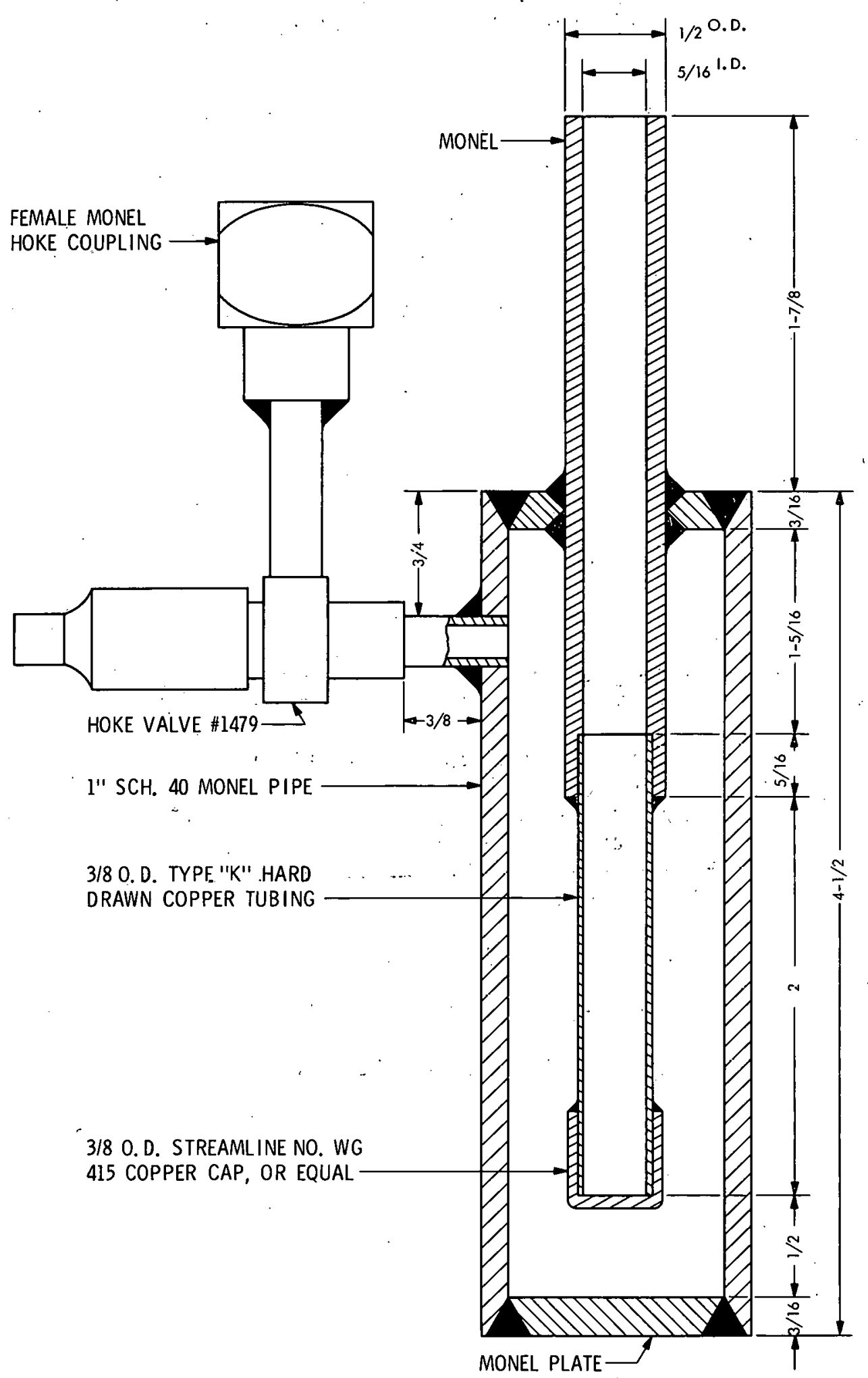

Figure 1

TRIPLE POINTT CELL 
Hoke valve silver-soldered near the top. A 3/8-inch-diameter thermowell extended through the top of the cylinder to within $1 / 2$ inch of the bottom. The top half of the thermowell was made of Monel and the bottom half was made of copper tubing. The thermowell was closed inside the cell with a 3/8-inch copper cap.

A calibrated gas pipette (figure 2) was used to dilute the molybdenum hexafluoride with milligram quantities of hydrogen fluoride. The pipette had a volume of about one liter, and was made of Monel with copper tubing as transfer lines. Pneumatic valves with neoprene gaskets were used in the transfer lines. The pressure was read from an automatic manometer with a digital. Veeder-Root reader in conjunction with a 50 millimeter pressure transmitter. An insulated box was maintained at $104^{\circ} \mathrm{C}$, and enclosed the volume chamber, valves, transmitter, hydrogen fluoride container, and all transfer lines (except the output line). The pipetted hydrogen fluoride was condensed into the $50 \mathrm{ml}$ triple point cells at liquid nitrogen condensation temperatures (about $-190^{\circ} \mathrm{C}$ ).

The freezing point bath was a stainless steel container enclosed in about an inch of Styrofoam with a split Styrofoam cover. The bath solution was a 1:1 mixture of isopropyl alcohol and water, and was maintained at about $0.3^{\circ} \mathrm{C}$ below the expected triple points. A thyratron control panel was used to control a variable speed circulating pump. The thyratron tube was activated by temperature changes of $\pm 0.05^{\circ} \mathrm{C}$ sensed with a thermistor inserted in the bath. A verneir was used to set the desired bath temperature. A motor-driven propeller, manually controlled by a transformer, circulated the solution in the bath (figure 3).

Temperature measurements were obtained using a ten-junction, copperconstantan thermocouple that was calibrated against a certified platinum resistance thermometer. Melting distilled water ice was used as the reference junction for the thermocouple. The emf produced was measured on a Leeds and Northrup potentiometer using an Electronik null point indicator. A standard calomel cell was used as a reference for the bridge circuit of the potentiometer.

\section{MATERIALS}

To separate the molybdenum hexafluoride from nonvolatile material, the molybdenum hexafluoride was distilled into a receiving trap maintained at $0^{\circ} \mathrm{C}$. Continuous vacuum pumping on the trap removed noncondensable matter. The condensed molybdenum hexafluoride was sampled and a triple point of $17.4 \pm 0.09^{\circ} \mathrm{C}$ was obtained, indicating no significant difference from the $17.4^{\circ} \mathrm{C}$ triple point of pure molybdenum hexafluoride (2). Infrared and mass spectrometer scans of the purit'ied material revealed no detectable impurities. A molal freezing (triple) point constant of $19.3^{\circ} \mathrm{C}$ per mole of molybdenum hexafluoride per 1000 grams of uranium hexafluoride, compared to the established constant of $19.2 \pm 0.7^{\circ} \mathrm{C}$ (3), was obtained, which indicated pure molybdenum hexafluoride.

Anhydrous hydrogen fluoride was prepared by selective sorption on sodium fluoride pellets. 


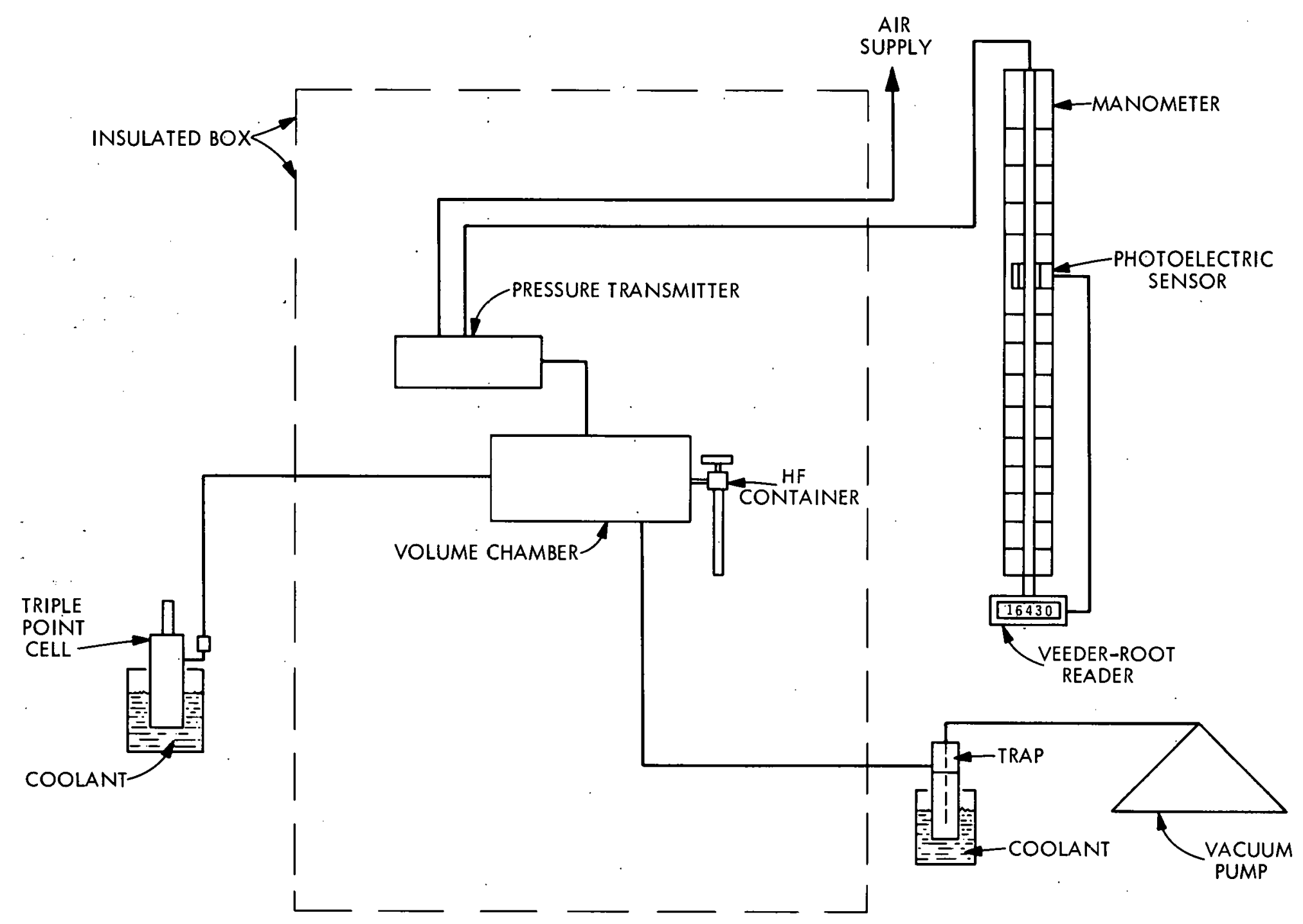

Figure 2

AUTOMATIC GAS PIPETTE 
DWG. NO. G-67-150

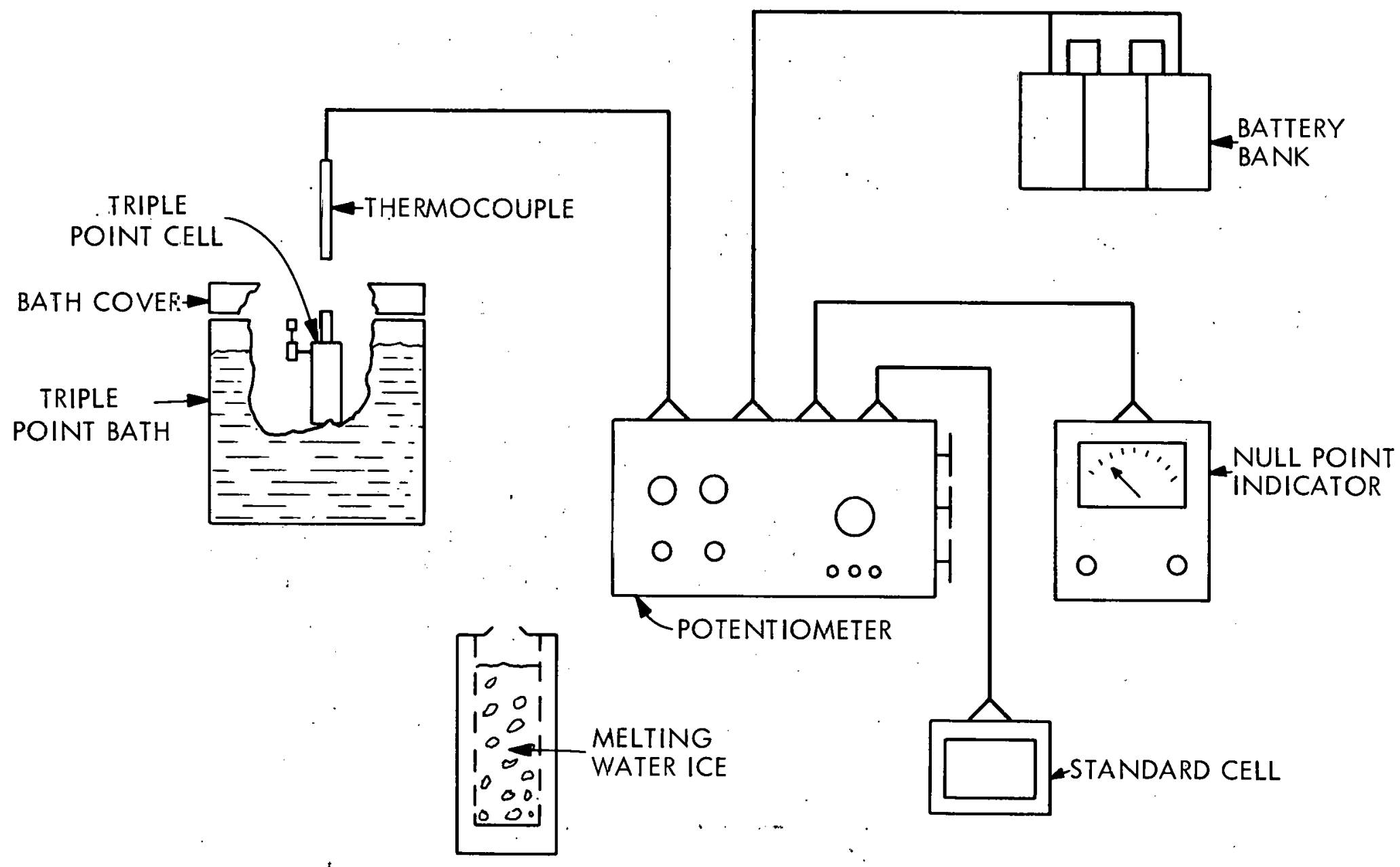

Figure 3

TRIPLE POINT MEASUREMENT ASSEMBLY 


\section{EXPERTMENTAL AND PROCEDURE}

\section{Preparing the Solutions}

The triple point of the molybdenum hexafluoride in each of the triple point cells was measured to confirm the purity of the solvent. The individual triple point cells contained the following quantities of molybdenum hexafluoride: FP-39 contained 36.5 grams; FP-47, 66.5 grams; FP-5, 95.3 grams. Each cell was individually attached to the fitting on the outlet line of the gas pipette. Liquid nitrogen was placed around the cell, and the cell permitted to cool to about $-190^{\circ} \mathrm{C}$. The pipette chamber and transfer lines were evacuated to less than $50 \times 10^{-3}$ torr. Hydrogen fluoride was then introduced to the isolated volume chamber of the pipette to a desired pressure, and subsequently condensed into the triple point cell. The quantity of condensed hydrogen fluoride was cal-culated from the pressure change and known volume of the pipette. The procedure was followed for each data point.

\section{Measuring the Triple Points}

Two $\mathrm{ml}$ of bath solution were placed in the thermowell of the freezing point cell to act as the heat transfer agent between the thermowell and the thermocouple. The triple point cell was placed in the constant temperature cooling bath previously adjusted to a temperature slightly (about $0.3^{\circ} \mathrm{C}$ ) below the expected triple point. The cooling curve was followed as the temperature decreased. When the molybdenum hexafluoride solution supercooled, the cell was tapped to start crystallization. Figure 4 is a representative triple point curve obtained in this manner.

$\underline{\text { Data }}$

Table I contains the following data per point for FP-39, FP-47, and FP-5: the cumulative grams of hydrogen fluoride added to the triple point cells, the cumulative weight percent and mole fraction of hydrogen fluoride in the triple point cells, the triple point depression $(\Delta t)$, the confidence limit of the temperature measurement, and the number of determinations per point. The data were fitted to a general parabolic least squares equation on an IBM 7090 computer. The equations in table II were so obtained.

Figure 5 is a plot of the mole fractions of hydrogen fluoride in molybdenum hexafluoride $\left(\mathrm{N}_{\boldsymbol{Z}}\right)$ versus the triple point depression $(\Delta t)$ as calculated from the equations in table II. 
11

DWG. NO. G-67-625

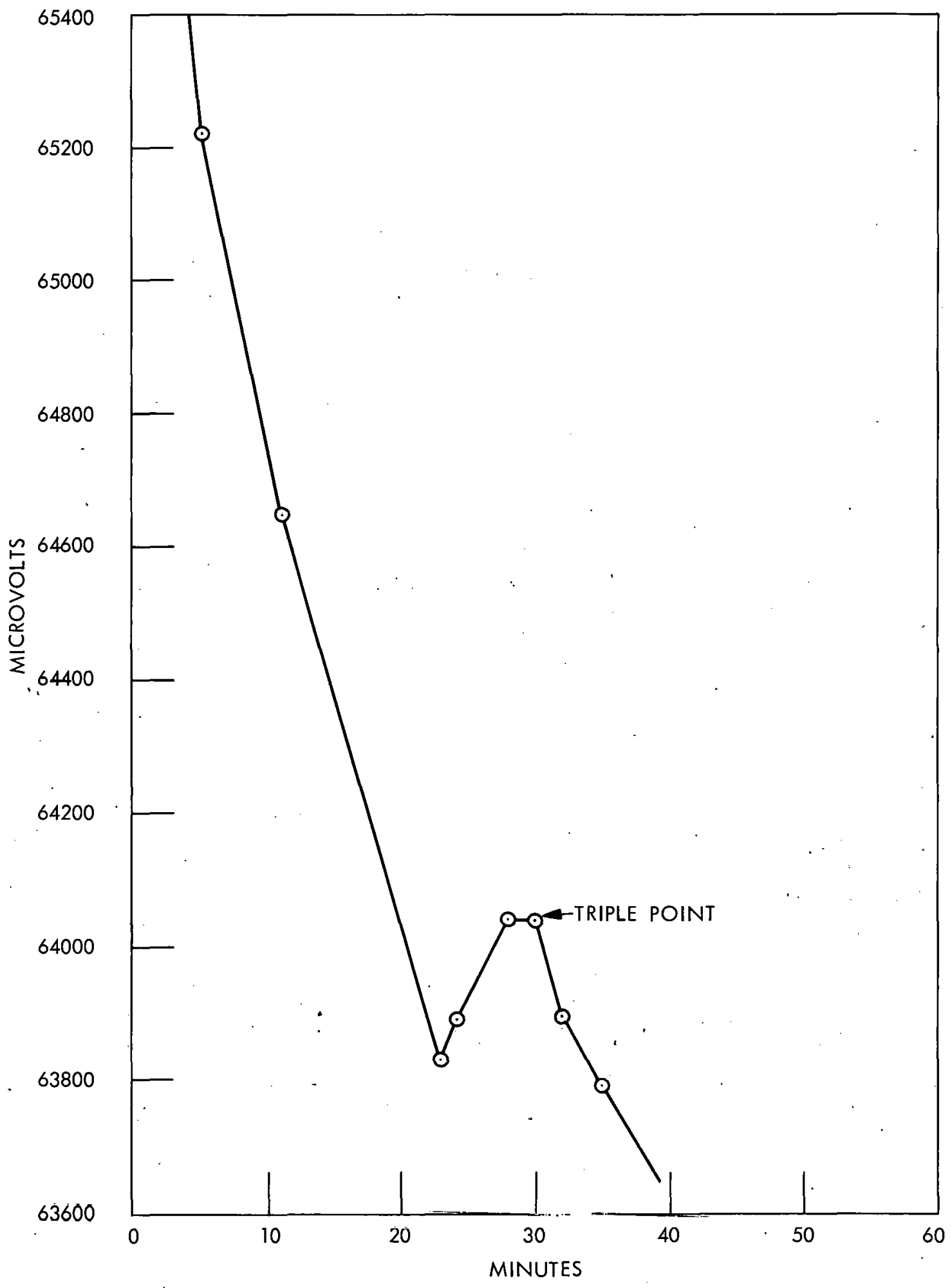

Figure 4

TYPICAL TRIPLE POINT CURVE 
TABLE I

THE LOWERIIVG OF THE MOLYBDENUM HEXAFLUORIDE TRIPLE POINT WITH HYDROGEN FLUORIDE

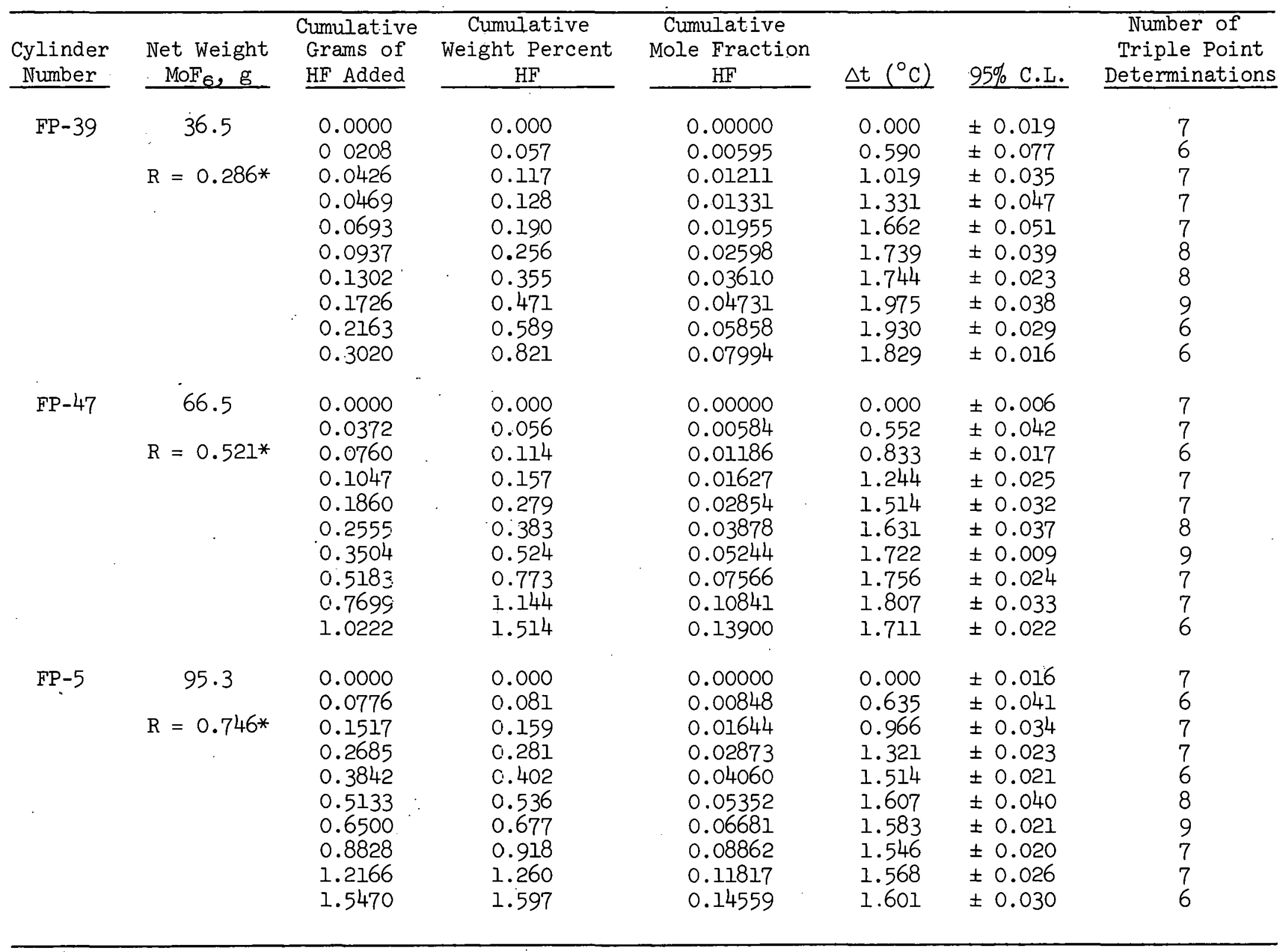

\footnotetext{
* $R$ is the ratio of liquid volume to total volume.
} 
DWG. NO. G-67-626

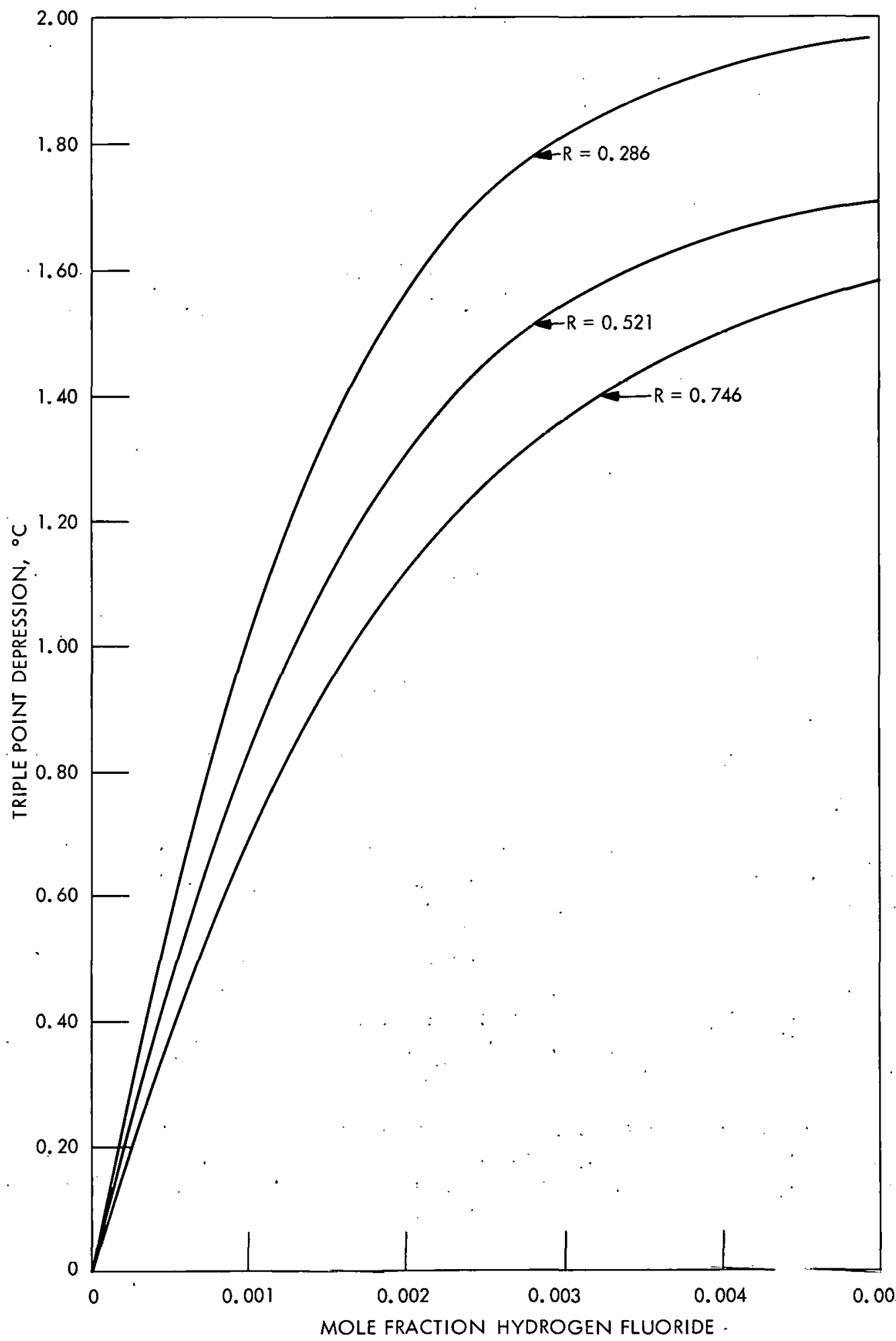

Figure 5

MOLYBDENUM HEXAFLUORIDE-HYDROGEN FLUORIDE TRIPLE POINT CURVES 
TABLE II

LEAST SQUARES EQUATIONS FROM THE THREE TRIPLE POINT CURVES OF HYDROGEN FLUOORIDE IN MOLYBDENUM HEXAFLUORIDE

\begin{tabular}{|c|c|c|}
\hline Cylinder Number & $\begin{array}{l}\text { Ratio of Liquid Volume } \\
\text { to Total Volume } \\
\end{array}$ & $\begin{array}{c}\text { General Equation } \\
\text { Constants } \\
\end{array}$ \\
\hline FP-39 & 0.286 & $\begin{array}{l}A=144.9 \\
B=-4031.0 \\
C=38900.4\end{array}$ \\
\hline FP-47 & 0.521 & $\begin{array}{l}A=113.1 \\
B=-2720.6 \\
C=22718.8\end{array}$ \\
\hline $\mathrm{FP}-5$ & 0.746 & $\begin{array}{lr}A= & 83.77 \\
B= & -1639.3 \\
C= & 11904.5\end{array}$ \\
\hline \multicolumn{3}{|c|}{$\begin{array}{l}* \mathrm{~N}_{2} \text { is the mole fraction hydrogen fluoride. } \\
\Delta t \text { is the triple point depression in }{ }^{\circ} \mathrm{C} .\end{array}$} \\
\hline
\end{tabular}

\section{Discussion}

The molybdenum hexafluoride-hydrogen fluoride binary system does not form an ideal solution since each cell is described by a different curve (figure 5). The differences between the curves represent the magnitude of the non-ideality. To determine the molal triple point curve for molybdenum hexafluoride, the curves of figure 5 , each representing a different ratio of liquid volume to total volume, need to be extrapolated to a curve representing a cell containing all liquid with no vapor volume. The extrapolated curve would be represented by a curve at the ratio of liquid volume to total volume of one $(R=1)$.

Using the ratios and equations of the three different cells from table II, the mole fractions of hydrogen fluoride was expressed as a function of the triple point depression and the ratio of liquid volume to total volume. Equation 2 represents this relationship.

$$
\Delta t=A\left(N_{2}\right)+B\left(N_{2}\right)^{2}+C\left(N_{2}\right)^{3}
$$

where

$$
\begin{aligned}
& A=159.86-129.19(R)+36.44\left(R^{2}\right) \\
& B=-3624.5+2965.0(R)-407.5\left(R^{2}\right) \\
& C=26239.0-17875.0(R)-1796.2\left(R^{2}\right)
\end{aligned}
$$

$\Delta t$ is the triple point depression of molybdenum hexafluoride

and $R$ is the ratio of liquid volume to total volume. 
Table III are values of $\mathrm{N}_{2}$ at various combinations of $R$ and $\Delta t$. Figure 6 is a plot of the observed triple point depression curves with the extrapolated curves at ratios of liquid volume to total volume values of one and zero. These latter curves were determined by substituting values of $\Delta t$ at $R=1$ and $R=0$ in equation 2 .

$$
\begin{array}{ll}
R=1 & \Delta t=67.11\left(N_{2}\right)-1067.0\left(N_{2}\right)^{2}+6567.8\left(N_{2}\right)^{3} \\
R=0 & \Delta t=159.9\left(N_{2}\right)-3624.5\left(N_{2}\right)^{2}+26239.0\left(N_{2}\right)^{3}
\end{array}
$$

Application to a Method of Analysis

From the position of the curves in figure 6 , it is indicated that the composition of the vapor phase is relatively richer with solvent than is the composition of the liquid phase in the binary system molybdenum hexafluoride-hydrogen fluoride. Thus to obtain the gross composition of such a solution, the disparity in the liquid and vapor compositions must be considered. For example, in cryroscopic measurements the same triple point depression would yield a gross composition dependent upon the amount of solution preserit in a given cell; and in withdrawing liquid samples from such a solution, the samples would represent only the liquid composition. The normal analytical situation usually involves gross compositions, and the triple point curves form a base for estimating gross compositions.

A cell with a total volume of $225 \mathrm{ml}$, and containing 460 grams of molybdenum hexafluoride, has a triple point depression of $0.90^{\circ} \mathrm{C}$. The ratio of liquid volume to total volume is

$$
R=\frac{G}{d V}
$$

where $R$ is the ratio of liquid volume to total volume

$G$ is the grams of solution

$d$ is the density of solution

$\mathrm{V}$ is the total volume of the container.

Thus for the system described above,

$$
R=460 /(2.55)(225)=0.80
$$

assuming the solute does not alter the density of the solvent.

The dashed lines in figure $7 \mathrm{~A}$ represent this solution, 'I'he dashed horizontal line from $\Delta t=0.90$ represents the triple point depression of the solution. The intersection of this horizontal line with the curve at. $R=1.0$ is the liquid composition: 0.0182 mole fraction hydrogen fluoride. The intersection with the curve $R=0.80$ is the gross composition: 0.0153 . The intersection with the curve $R=0.0$ is the vapor composition: 0.0062 . 
TABLE III

MOLE FRACTION HYDROGEN FLUORIDE IN MOLYBDENUM HEXAFLUORIDE AT DIFFERENT RATIOS OF LIQUID VOLUME TO TOTAL VOLUME

\begin{tabular}{|c|c|c|c|c|c|c|c|}
\hline Ratio c & $\begin{array}{l}\text { of Liquid Volume to } \\
\text { Total Volume }\end{array}$ & 1.0 & 0.8 & 0.6 & 0.4 & 0.2 & 0.0 \\
\hline Triple F & Point Depression, ${ }^{\circ} \mathrm{C}$ & & Mol & Fractions & Aydrogen FI & & \\
\hline & 0.0 & 0.0000 & 0.0000 & 0.0000 & 0.0000 & 0.0000 & 0.0000 \\
\hline & 0.1 & 0.0012 & 0.0010 & 0.0009 & 0.0008 & 0.0006 & 0.0005 \\
\hline & 0.2 & 0.0029 & 0.0023 & 0.0017 & 0.0016 & 0.0013 & 0.0012 \\
\hline & 0.3 & 0.0047 & 0.0037 & 0.0028 & 0.0025 & 0.0023 & 0.0019 \\
\hline & 0.5 & 0.0066 & 0.0053 & 0.0040 & 0.0036 & 0.0031 & 0.0026 \\
\hline & 0.5 & 0.0087 & 0.0071 & 0.0053 & 0.0046 & 0.0039 & 0.0033 \\
\hline & 0.6 & 0.0108 & 0.0090 & 0.0067 & 0.0057 & 0.0047 & 0.0041 \\
\hline & 0.7 & .0 .0130 & 0.0110 & 0.0082 & 0.0069 & 0.0056 & 0.0048 \\
\hline & 0.8 & 0.0157 & 0.0131 & 0.0098 & 0.0081 & 0.0065 & 0.0055 \\
\hline & 0.9 & 0.0182 & 0.0153 & 0.0117 & 0.0095 & 0.0074 & 0.0062 \\
\hline & 1.0 & 0.0211 & 0.0180 & 0.0139 & 0.0111 & 0.0083 & 0.0069 \\
\hline & 1.1 & 0.0246 & 0.0211 & 0.0163 & 0.0130 & 0.0095 & 0.0078 \\
\hline & 1.2 & 0.0285 & 0.0247 & 0.0192 & 0.0146 & 0.0108 & 0.0089 \\
\hline & 1.3 & 0.0331 & 0.0290 & 0.0228 & 0.0167 & 0.0122 & 0.0100 \\
\hline & 1.5 & 0.0390 & $0.0342-$ & 0.0268 & 0.0190 & 0.0138 & 0.0110 \\
\hline & 1.5 & 0.0479 & 0.0420 & 0.0321 & 0.0220 & 0.0155 & 0.0124 \\
\hline & 1.6 & - & -- & 0.0418 & 0.0261 & 0.0174 & 0.0139 \\
\hline & 1.7 & -- & -- & -- & 0.0322 & 0.0199 & 0.0154 \\
\hline & 1.8 & -- & -- & -- & -- & 0.0231 & 0.0172 \\
\hline & 1.9 & -- & -- & -- & -- & 0.0280 & 0.0190 \\
\hline & 2.0 & -- & - & -- & - & 0.0500 & 0.0210 \\
\hline & 2.1 & -- & -- & -- & - & -- & 0.0236 \\
\hline & 2.2 & -- & -- & -- & -- & -- & 0.0278 \\
\hline
\end{tabular}


DWG. NO. G-67-627

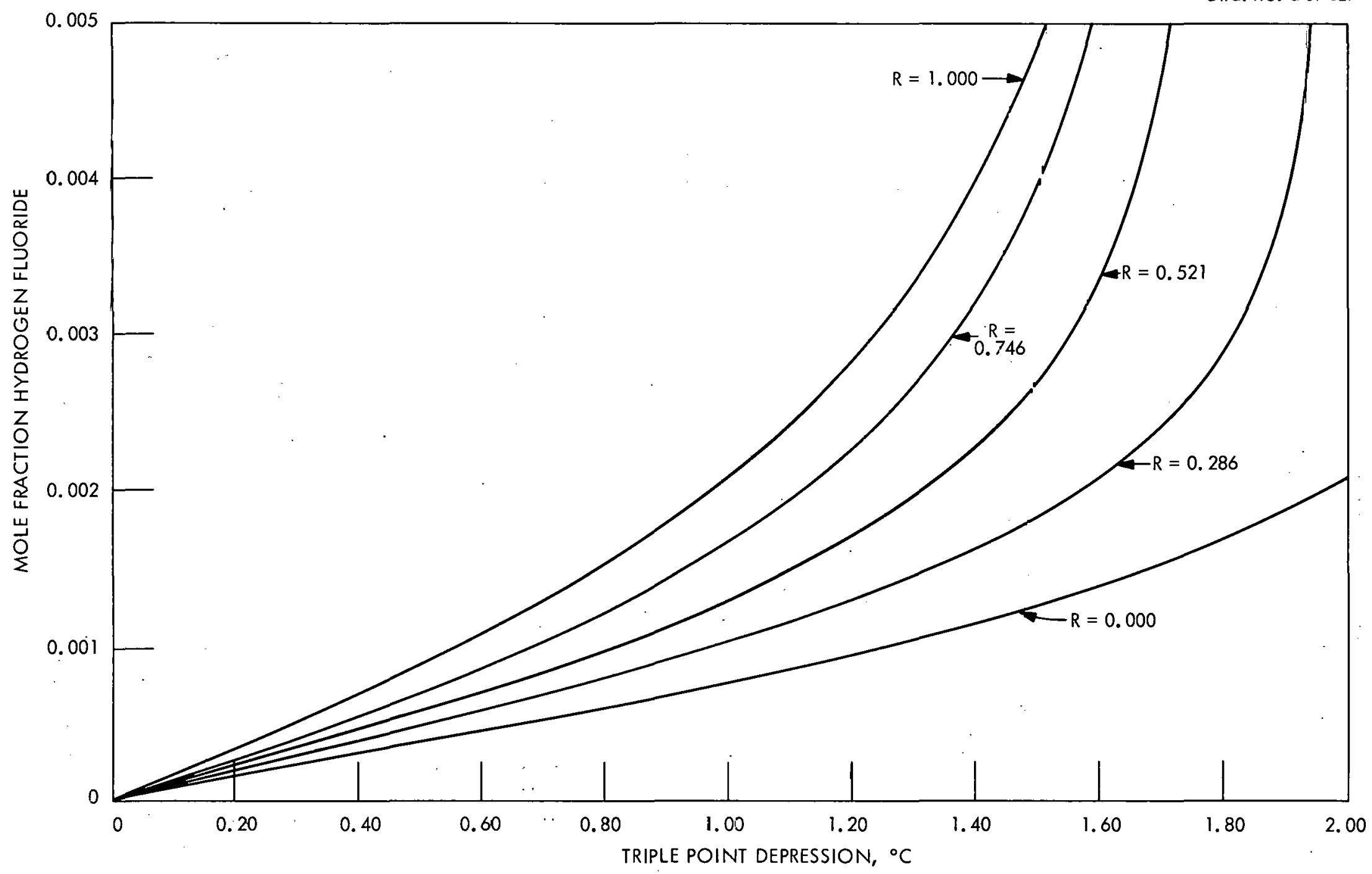

Figure 6 MOLYBDENUM HEXAFLUORIDE-HYDROGEN FLUORIDE TRIPLE POINT CURVES 
DWG. NO. G-67-624

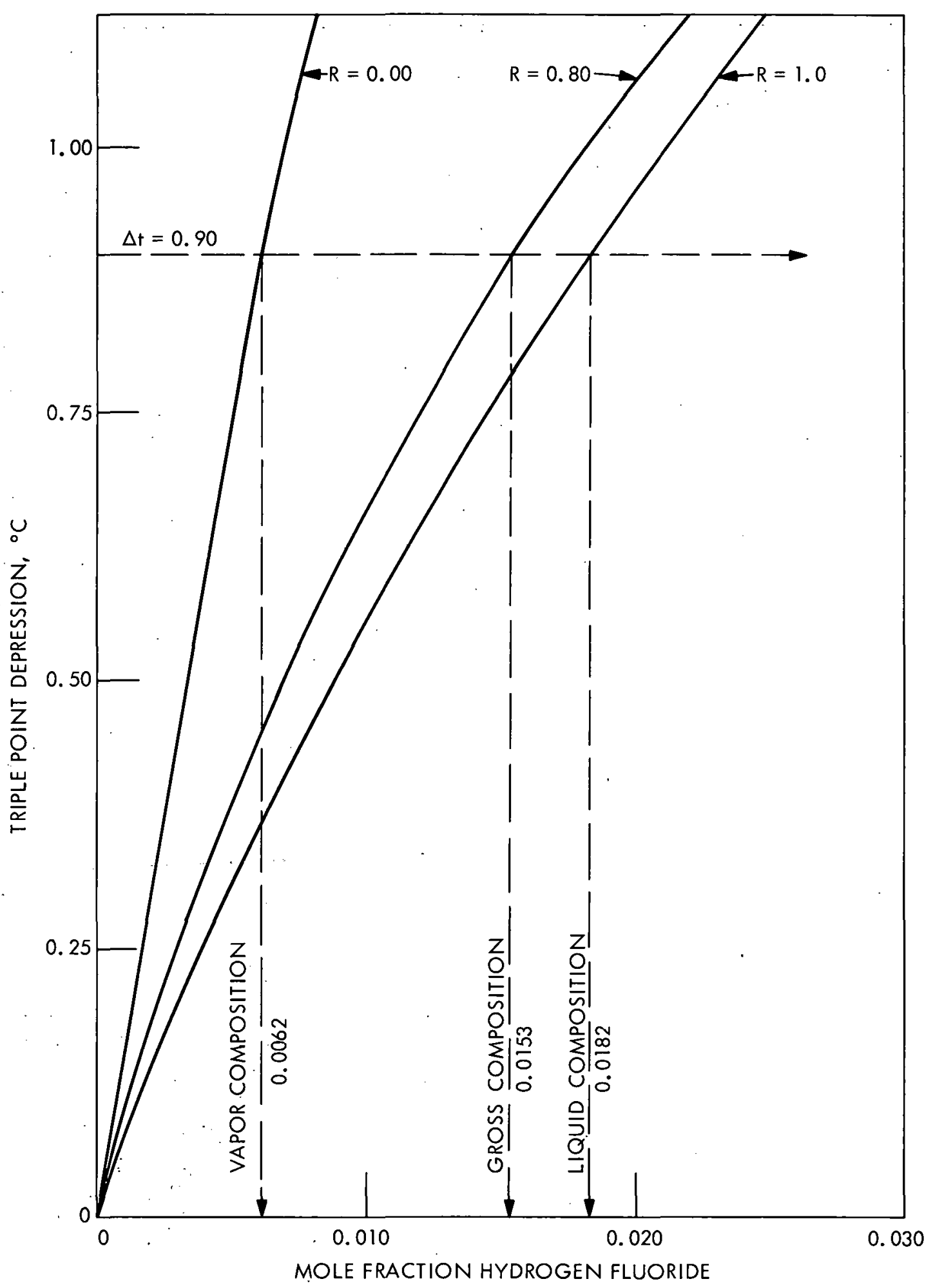

Figure $7 A$

GROSS, VAPOR, AND LIQUID COMPOSITION OF THE SYSTEM MOF ${ }^{-H F}$ 
If such a system as described above were liquid-sampled and gravimetrically analyzed for mole fraction molybdenum hexafluoride, the obtained result would represent the liquid phase only. Since material was withdrawn at the liquid composition, the gross composition remaining in the container after sampling would now be different, and the composition of the liquid and vapor phase would readjust to the new conditions.

To estimate the change resulting in the gross, liquid, and vapor compositions due to withdrawing a liquid portion of the solution, assume that 345 grams of liquid were withdrawn from the solution represented by the dashed lines in figure $7 \mathrm{~A}$. Thus the container now has 115 grams of solution with a ratio of liquid to total volume of $115 /(2.55)(225)=0.20$. To determine the gross, liquid, and vapor compositions of the remaining solution after the withdrawal, generate a line parallel to the triple point depression axis from the intersection $(\Delta t=0.90, R=0.20)$ to the intersection with $R=0.80$. From this latter intersection, generate a line parallel to the mole fraction axis. The intersection of this latter line with the curve $R=1.0$ is the liquid composition: 0.0091 mole fraction hydrogen fluoride. The intersection with the curve $R=0.20$ is the gross composition: 0.0041 mole fraction. And the intersection with the curve $R=0.0$ is the vapor composition: 0.0035 mole fraction. This procedure is illustrated in figure 7B. Identical results may be obtained by determining the triple point depression after withdrawing the sample (estimated graphically in figure $7 \mathrm{~A}$ by $\Delta t=0.52$ ). After determining the triple point depression, Equation 2 may be used to solve for the desired compositions.

Figure 8 is a graphic presentation of the expected gross, liquid, and vapor compositions of a typical molybdenum hexafluoride-hydrogen fluoride binary solution. Note that when the ratio of liquid volurie to total volume equals one (all liquid), the gross and liquid compositions are equal. When the ratio of liquid volume to total volume equals zero (all vapor), the gross and vapor compositions are equal.

\section{ACKINOWLEDGEMENTS}

The author wishes to acknowledge Mr. R. J. Wertz for his many suggestions and general guidance in the course of this study, and Miss Jane Howell for her treatment of the data. 
20

DWG. NO. G-67-623

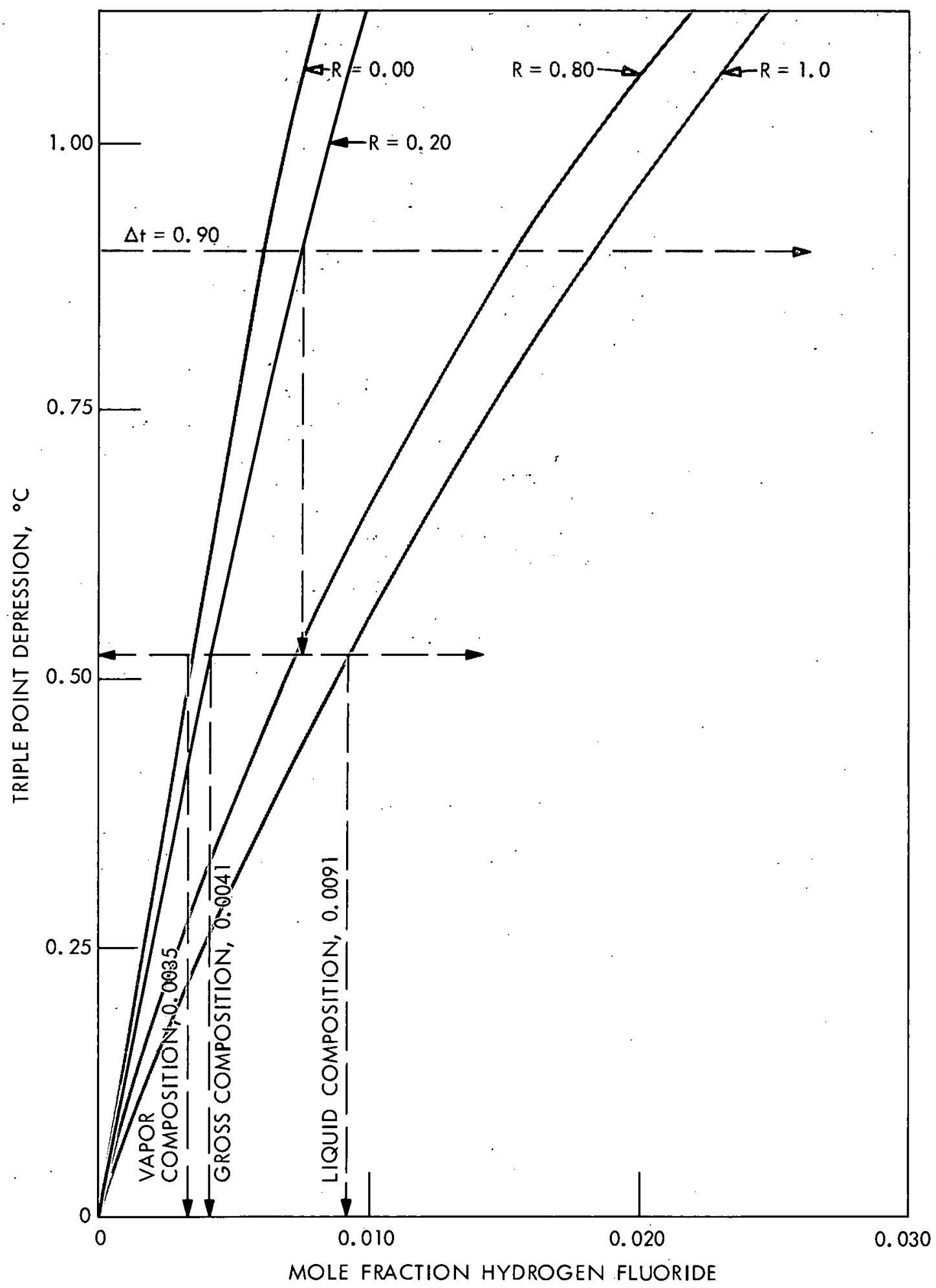

Figure $7 \mathrm{~B}$

GROSS, VAPOR, AND LIQUID COMPOSITION OF THE SYSTEM MOF $6^{-H F}$ 
DWG. NO. G-67-628

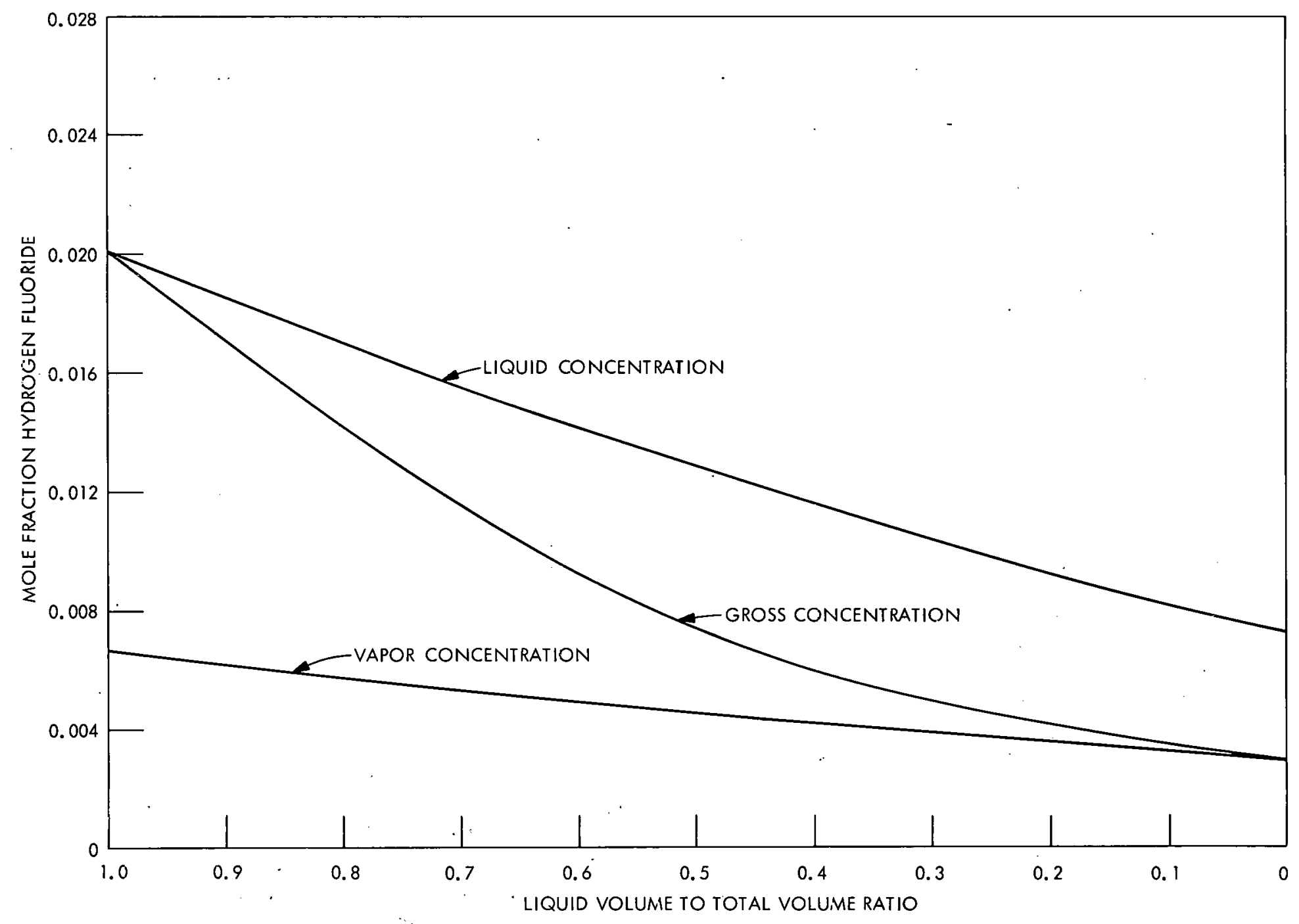

Figure 8

MOLE FRACTION HYDROGEN FLUORIDE DISTRIBUTION FOR

A TYPICAL MOF 6 -HF SOLUTION 


\section{BIBLIOGRAPHY}

1. Ryss, I. G., The Chemistry of Fluorine and Its Organic Compounds, United States Atomic Energy Commission, 1960 (AEC-tr-3927, part 2), p. 374 .

2. Hargreaves, G. B. and Cody, G., "The Vapor Pressure of Some Heavy Transition Metal Fluorides," J.Amer. Chem. Soc., No. 305 (April 1961), pp. 1563-74.

3. Hedge, W. D., The Molal Freezing Point Depression Curve of Uranium Hexafluoride and Its Application to a Method of Analysis, Union Carbide Corporation, Nuclear Division, Oak Ridge Gaseous Diffusion Plant, January 17, 1967 ( $\mathrm{K}-1677)$. 